Article

\title{
House Flies (Musca domestica) Pose a Risk of Carriage and Transmission of Bacterial Pathogens Associated with Bovine Respiratory Disease (BRD)
}

\author{
Saraswoti Neupane ${ }^{1}$, Dana Nayduch ${ }^{2}$ (D) and Ludek Zurek ${ }^{1,3,4, *(1)}$ \\ 1 Department of Entomology, Kansas State University, Manhattan, KS 66502, USA; sneupane@ksu.edu \\ 2 Arthropod-borne Animal Diseases Research Unit, USDA-ARS, 1515 College Avenue, Manhattan, KS 66502, \\ USA; dana.nayduch@usda.gov \\ 3 Department of Pathology and Parasitology, Center for Zoonoses, University of Veterinary and \\ Pharmaceutical Sciences, Central European Institute of Technology, 61242 Brno, Czech Republic \\ 4 Department of Chemistry and Biochemistry, Mendel University, 61300 Brno, Czech Republic \\ * Correspondence: zureklu@vfu.cz; Tel.: +420-702-127-502
}

Received: 26 September 2019; Accepted: 17 October 2019; Published: 18 October 2019

\begin{abstract}
House flies are important nuisance pests in a variety of confined livestock operations. More importantly, house flies are known mechanical vectors of numerous animal and human pathogens. Bovine respiratory disease (BRD) is an economically important, complex illness of cattle associated with several bacteria and viruses. The role of flies in the ecology and transmission of bacterial pathogens associated with BRD is not understood. Using culture-dependent and culture-independent methods, we examined the prevalence of the BRD bacterial complex Mannheimia haemolytica, Pasteurella multocida and Histophilus somni in house flies collected in a commercial feedlot from a pen with cattle exhibiting apparent BRD symptoms. Using both methods, M. haemolytica was detected in $11.7 \%$ of house flies, followed by P. multocida (5.0\%) and H. somni (3.3\%). The presence of BRD bacterial pathogens in house flies suggests that this insect plays a role in the ecology of BRD pathogens and could pose a risk as a potential reservoir and/or a vector of BRD pathogens among individual cattle and in their environment.
\end{abstract}

Keywords: bovine respiratory disease; house fly; bacterial pathogen; cattle

\section{Introduction}

Bovine respiratory disease (BRD) is a major problem in feedlot cattle production in the USA, and outbreaks can result in significant economic losses [1,2]. The onset of disease is primarily linked to environmental stressors such as shipping, crowding and changes in diet [3] that presumably cause immunosuppression and subsequent infections from various viral and bacterial pathogens [2,4]. The bacteria associated with BRD, Mannheimia haemolytica, Pasteurella multocida, Histophilus somni, and Mycoplasma bovis, are routinely isolated from cattle with BRD [5-7]. The prevalence of these bacteria in cattle production systems is highly variable [8]. Most studies have focused on management strategies to avoid disease and on detection, characterization, drug resistance and drug development for these pathogens, but there is little information about pathogen ecology and transmission dynamics.

House flies are among the most common insect pests in confined animal facilities, including cattle feedlots. Larvae develop in microbe-rich environments such as those contaminated with animal feces. Adult flies frequent these locations and readily feed upon septic substrates (e.g., manure), as well as animal wounds, secretions, food and water [9]. Therefore, adult flies serve as both reservoirs and vectors of microbes, including many bacterial pathogens [10]. House flies carry bacteria in their digestive tract and on the body surface and disseminate/release them by regurgitation from the foregut, 
by defecation, and by dislodging bacterial cells from the body surface, primarily from their tarsi [10]. While house flies have been implicated in the carriage and transmission of other pathogens of cattle, including some that are zoonotic [11-14], their association with BRD bacteria or their role in the transmission of BRD bacteria has not been examined to date.

In this study, we aimed to assess the prevalence of the BRD-associated bacterial pathogens M. haemolytica, P. multocida and $H$. somni in house flies from a commercial cattle feedlot with animals suffering from BRD symptoms using culture-dependent and culture-independent methods.

\section{Materials and Methods}

\subsection{Bacterial Isolates and Culture Methods}

Pure cultures of BRD-associated bacterial pathogens M. haemolytica DM1 and P. multocida DM1 were received from Dr. Derek Mosier, Kansas State University, while H. somni B55 was obtained from Dr. Brian Lubbers, Kansas State University. M. haemolytica and P. multocida were cultured on brain heart infusion agar (BHI; BD, Franklin Lakes, NJ, USA) supplemented with $5 \%$ sheep blood (Cedarlane ${ }^{\circledR}$, Burlington, NC, USA) and antimicrobials (per ml: $5 \mu \mathrm{g}$ neomycin, $5 \mu \mathrm{g}$ vancomycin, $50 \mu \mathrm{g}$ sodium azide and $100 \mu \mathrm{g}$ cycloheximide) and used as a reference (positive control) for both culture-dependent and -independent methods. The bacteria were incubated at $37^{\circ} \mathrm{C}$ for $24 \mathrm{~h}$. H. somni was cultured on chocolate agar (CA) supplemented with $5 \%$ sheep blood and antimicrobials as above. Bacteria were incubated for $48 \mathrm{~h}$ at $37^{\circ} \mathrm{C}$ in a BBL GasPak system (Becton, Dickinson and Company, Franklin Lakes, NJ, USA) containing a CampyPak Plus ${ }^{\mathrm{TM}}$ microaerophilic system generator (Becton, Dickinson and Company, Franklin Lakes, NJ, USA). These bacterial isolates were also used as positive controls.

\subsection{Field Site, Sample Collection and Processing}

A commercial cattle operation located in Reading, KS ( $\left.38^{\circ} 37^{\prime} 31^{\prime \prime} \mathrm{N}, 95^{\circ} 58^{\prime} 23^{\prime \prime} \mathrm{W}\right)$, was chosen as the collection site on the basis of information obtained from the owner which indicated the presence of cattle with respiratory health issues. House flies were collected two times from an area outside an open-air fenced sick-cattle pen at the feedlot. On the first sampling date (13 June 2018), 30 house flies (12 males and 18 females) were captured by sweep, immediately transferred to a sterile Ziploc ${ }^{\circledR}$ bag, kept cool on ice during transport to the laboratory, and processed within $\sim 4 \mathrm{~h}$. On the second sampling date (26 June 2018), 30 house flies (18 males and 12 females) were captured from the same area and processed as above.

In the laboratory, each fly was homogenized in $500 \mu \mathrm{L}$ sterile phosphate-buffered saline (PBS) ( $\mathrm{pH}$ 7.2; MP Biomedicals, LLC, Irvine, CA, USA). Two aliquots of fly homogenate were prepared for the subsequent detection of bacteria: a $200 \mu \mathrm{L}$ aliquot was used for culture-dependent analysis (pathogen culture), and the remaining $300 \mu \mathrm{L}$ was stored at $-80^{\circ} \mathrm{C}$ for detection of pathogens using a culture-independent method (DNA extraction, PCR and sequencing).

\subsection{Culture-Dependent Method}

A fly homogenate $(100 \mu \mathrm{L})$ was plated on blood agar, and another aliquot $(100 \mu \mathrm{L})$ on chocolate agar medium supplemented with antibiotics and cultured as described above. Due to constraints of microaerophilic conditions, we plated only 54 fly homogenates on chocolate agar for culturing of H. somni. Colonies with morphology similar to those of the reference isolates M. haemolytica and/or P. multocida and H. somni (Klima et al. [5]) were sub-cultured on blood or chocolate agar, respectively. Colonies exhibiting similar morphologies were enumerated to estimate their abundance (colony-forming units, CFU, per fly). Species identification was confirmed by PCR amplification and sequencing as described below. 


\subsection{DNA Preparation, PCR and Sequencing of Cultured Bacteria}

A single colony (selected isolates and reference isolates) was picked from a pure culture and suspended in $100 \mu \mathrm{L}$ of nuclease-free water, boiled for $15 \mathrm{~min}$ at $100{ }^{\circ} \mathrm{C}$ and centrifuged at $10,000 \times$ $g$ for $3 \mathrm{~min}$. The supernatant was used as a DNA template for PCR. Species-specific primers HS [5], Leukotoxin A [15] and KMT1_2 (hydrolase family) [16,17] were chosen for H. somni, M. haemolytica and P. multocida identification, respectively (Table 1). Further, a universal bacterial primer pair targeting the $16 \mathrm{~S}$ rRNA gene (8F and 806R) $[18,19]$ was used as a reaction control. PCR assays with single pairs of primer sets were carried out using DNA extracted from selected bacterial isolates; reference bacterial isolates were used as positive controls, and nuclease-free water was used as a negative reaction control.

In addition, the species-specific primer pairs were optimized for the detection of bacterial pathogens directly in the fly homogenates spiked with a reference bacterial culture (positive controls). The DNA was extracted and amplified using species-specific primer pairs for H. somni, M. haemolytica and P. multocida, as described below. The detection levels of the specific primers were $60 \mathrm{CFU} / \mu \mathrm{L}$, $180 \mathrm{CFU} / \mu \mathrm{L}$ and $115 \mathrm{CFU} / \mu \mathrm{L}$ for H. somni, M. haemolytica and P. multocida, respectively.

Each PCR reaction $(25 \mu \mathrm{L})$ contained a final concentration of $1 \times$ PCR Master Mix (Promega, Madison, WI, USA), $0.2 \mu \mathrm{M}$ of each primer (Bio-Synthesis Inc, Lewisville, TX, USA) and $2.5 \mu \mathrm{L}$ of DNA template. The PCR was performed using a DNA Engine ${ }^{\circledR}$ Thermal Cycler (Bio-Rad, Hercules, CA, USA), with the following reaction conditions: $94{ }^{\circ} \mathrm{C}$ for $3 \mathrm{~min}$, followed by 25 cycles at $94{ }^{\circ} \mathrm{C}$ for $30 \mathrm{~s}, 55$ or $58^{\circ} \mathrm{C}$ (Table 1) for $30 \mathrm{~s}$ and $72{ }^{\circ} \mathrm{C}$ for $30 \mathrm{~s}$; then, $72{ }^{\circ} \mathrm{C}$ for $5 \mathrm{~min}$. To confirm amplification, $5 \mu \mathrm{L}$ of PCR product was visualized on $1 \%$ agarose gel via gel electrophoresis. Amplicons were purified using DNA Clean and Concentrator-5 kit (Zymo Research Corporation, Irvine, CA, USA) as described in the manufacturer's instructions. Purified amplicons were sequenced using the Sanger sequencing method by Genewiz (https://www.genewiz.com/en, GENEWIZ, LLC, South Plainfield, NJ, USA). The sequences were compared with those in the National Center for Biotechnology Information non-redundant reference dataset using a basic local alignment search tool [20]. Sequence identity was confirmed when a sequence was $\geq 99 \%$ similar to a reference species.

Table 1. PCR primers for bacterial species confirmation.

\begin{tabular}{|c|c|c|c|c|c|c|}
\hline Bacterium & $\begin{array}{c}\text { Primer } \\
\text { Name (s) }\end{array}$ & Forward $5^{\prime}-3^{\prime}$ & Reverse $5^{\prime}-3^{\prime}$ & $\begin{array}{c}\text { Annealing } \\
\text { Temperature } \\
\left({ }^{\circ} \mathrm{C}\right)\end{array}$ & $\begin{array}{l}\text { Fragment } \\
\text { Size }\end{array}$ & Reference \\
\hline $\begin{array}{l}\text { Histophilus } \\
\text { somni }\end{array}$ & HS & GAAGGCGATTAGTTTAAGAG & TTCGGGCACCAAGTRTTCA & 55 & 400 & [5] \\
\hline $\begin{array}{l}\text { Mannheimia } \\
\text { haemolytica }\end{array}$ & Leuk-A & CTTACATTTTAGCCCAACGTG & TAAATTCGCAAGATAACGGG & 58 & 497 & [15] \\
\hline $\begin{array}{l}\text { Pasteurella } \\
\text { multocida }\end{array}$ & KMT1_2 & GTGTGTTGAGCCAATCTGCT & GCTGTAAACGAACTCGCCAC & 55 & 283 & {$[16,17]$} \\
\hline Bacteria & $8 \mathrm{~F}, 806 \mathrm{R}$ & AGAGTTTGATCCTGGCTCAG & GGACTACCAGGGTATCTAAT & 52 & 799 & {$[18,19]$} \\
\hline
\end{tabular}

\subsection{Culture-Independent Method}

Total genomic DNA was extracted from $300 \mu \mathrm{L}$ of fly homogenate using the ZymoBIOMICS DNA kit (Zymo Research Corporation, Irvine, CA, USA) and amplified using pathogen-specific primer pairs for H. somni (HS), M. haemolytica (Leuk-A) and P. multocida (KMT1-2) (Table 1). The same PCR reaction conditions as those reported above were used, and amplicon purification, sequencing and analysis were performed as described above.

\section{Results}

Prevalence of M. haemolytica, P. multocida and H. somni in House Flies from a BRD-Affected Commercial Feedlot

In total, 60 individual house flies were processed, and the homogenates were cultured to detect $M$. haemolytica and P. multocida, while 54 individuals were processed for culturing of H. somni. M. haemolytica 
was isolated from two female house flies, whereas P. multocida was isolated from three females. Similarly, H. somni was isolated from one female out of 54 house flies, and CFUs were too numerous to count (TNTC; Table 2). The number of CFUs of M. haemolytica ranged between 125 and 1000 CFUs/fly, while those of P. multocida ranged between 310 and 1000 CFUs/fly (Table 2). All culture-positive flies were females and were collected during the first sampling date.

Table 2. Respiratory disease (BRD)-associated bacteria isolated from house flies from a BRD-affected feedlot.

\begin{tabular}{cccc}
\hline FlyID & Fly Sex $^{\text {a }}$ & Bacterium & CFU/fly \\
\hline L1F3 & Female & M. haemolytica & $\sim 1000$ \\
L1F13 & Female & M. haemolytica & 125 \\
L2F2 & Female & P. multocida & 1000 \\
L1F8 & Female & P. multocida & 750 \\
L1F2 & Female & P. multocida & 310 \\
L1F2 & Female & H. somni & TNTC *
\end{tabular}

${ }^{*}$ Colony-forming units (CFUs) were too numerous to count (TNTC) by the culture method used. ${ }^{\text {a }}$ All BRD-associated bacteria were isolated from house flies collected on the first sampling date.

The culture-independent direct PCR method revealed that out of the total 60 house flies, 4 flies from the first sampling date and two flies from the second sampling date were positive for M. haemolytica (Table 3), and this was confirmed by sequencing. However, no house flies were PCR-positive for P. multocida. Two out of 60 house flies were positive for H. somni by PCR and sequencing (Table 3), and both samples were collected on the first sampling date. Taken together, the culture-dependent and -independent methods detected at least one of the BRD pathogens in eight house flies, of which seven were females: all three pathogens from one female fly and two of three pathogens from two female flies. Using either method, the overall prevalence of M. haemolytica, P. multocida and H. somni in house flies collected from the commercial feedlot was $11.7 \%, 5.0 \%$ and $3.3 \%$, respectively.

Table 3. Prevalence (+) of M. haemolytica, P. multocida and H. somni in house flies from a bovine respiratory disease-affected feedlot.

\begin{tabular}{|c|c|c|c|c|c|c|c|c|c|}
\hline \multirow{2}{*}{ FlyID } & \multirow{2}{*}{ Fly Sex ${ }^{a}$} & \multirow{2}{*}{$\begin{array}{l}\text { Sampling } \\
\text { Date }^{b}\end{array}$} & \multicolumn{2}{|c|}{ M. haemolytica } & \multicolumn{2}{|c|}{ P. multocida } & \multicolumn{2}{|c|}{ H. somni } & \multirow{2}{*}{$\begin{array}{c}\text { Bacteria } \\
\text { PCR }\end{array}$} \\
\hline & & & Culture & $\begin{array}{l}\text { Direct } \\
\text { PCR }\end{array}$ & Culture & $\begin{array}{l}\text { Direct } \\
\text { PCR }\end{array}$ & Culture & $\begin{array}{l}\text { Direct } \\
\text { PCR }\end{array}$ & \\
\hline L1F2 & F & 1 & & + & + & & + & + & + \\
\hline L1F3 & $\mathrm{F}$ & 1 & + & + & & & & + & + \\
\hline L1F8 & $\mathrm{F}$ & 1 & & + & + & & & & + \\
\hline L1F13 & $\mathrm{F}$ & 1 & + & & & & & & + \\
\hline L2F2 & $\mathrm{F}$ & 1 & & & + & & & & + \\
\hline L2F4 & $\mathrm{F}$ & 1 & & + & & & & & + \\
\hline L3F29 & M & 2 & & + & & & & & + \\
\hline L3F30 & $\mathrm{F}$ & 2 & & + & & & & & + \\
\hline
\end{tabular}

${ }^{\mathrm{a}}$ Fly sex $\mathrm{F}=$ female, $\mathrm{M}=$ male. ${ }^{\mathrm{b}}$ Sampling Date: 1 = First sampling date, 2 = Second sampling date.

\section{Discussion}

The BRD pathogen complex includes M. haemolytica, P. multocida, H. somni, Mycoplasma bovis, bovine respiratory syncytial virus, and bovine herpesvirus-1 [2]. The bacterial BRD pathogens can be found in the respiratory tract of both sick and healthy cattle [21,22]. The disease onset is linked to various stressors such as weather conditions [23] and transportation [24]. Such stressors may cause immunosuppression in cattle that ultimately contributes to the respiratory tract microbiota becoming pathogenic [2,4]. Transmission of BRD pathogens among cattle is considered to occur via direct contact with infected animals [25] or by ingesting feed and water contaminated with nasal discharge containing these bacteria; however, transmission via insect vectors has not been explored previously. Our study 
focused on determining the prevalence of the three main bacterial BRD pathogens in house flies, one of the primary arthropod pests of confined livestock operations. Using both culture-based and PCR-based methods, we demonstrated that $>3 \%$ of house flies from a BRD-affected commercial feedlot carried at least one of the BRD-associated bacterial pathogens (i.e., M. haemolytica, P. multocida or H. somni). This suggests that house flies could serve a role in BRD outbreaks by harboring and potentially transmitting BRD bacterial pathogens.

The culture-based method revealed that a high percentage of female house flies ( $16.7 \%$ of total females) carried at least one of the BRD bacterial pathogens. Thus, our preliminary findings suggest that females may pose a higher risk of dissemination of viable bacteria than male flies. Also, when the culture-based and direct PCR methods were combined, seven of eight $(87.5 \%)$ house flies that possessed any one of these pathogens were females. Sex-specific behaviours of house flies may compel females to feed on more proteinaceous substances and to interact more frequently with microbe-rich substrates than males, due to their reproductive needs (i.e., anautogeny, oviposition sites) [26]. We, therefore, speculate that as female flies more frequently feed on microbe- and nutrient-rich substrates in a feedlot, such as manure, animal secretions, wounds, animal feed, etc., they become contaminated with pathogens shed from infected animals. Indeed, M. haemolytica, P. multocida and H. somni are routinely cultured from tonsillar tissues and lung tissues of infected (sick) cattle and can be particularly abundant in nasal secretions $[5,7,15,27]$. Consequently, house flies likely acquire BRD pathogens by feeding on either nasal secretions or contaminated feed and water. Once flies are contaminated with bacterial pathogens, either on their surface or by ingestion, they can disseminate these bacteria into a range of new environments, including locations with healthy cattle. However, since we homogenized the whole flies, we could not differentiate whether the BRD bacteria originated from the fly digestive tract, from the body surface or from both. More detailed studies focused on the vectorial capacity of house flies for BRD pathogens are warranted.

We also found that the prevalence of these bacteria in this feedlot seemed to be associated with the presence of and duration of sick cattle in the sick pen. On the first sampling date, when all three bacterial pathogens were isolated, the pen contained sick calves that had been there for several days. In contrast, on the second sampling date, new sick calves had arrived on the day of collection. To fully understand the role of house flies in the ecology of these microbes, from acquisition to harbouring and to dissemination, it will be paramount in future studies to also measure the prevalence and persistence of BRD pathogens in relation to the infected animals (and their secretions) as well as their environment (feed, water, fomites).

Our study used both culture-dependent and -independent methods to successfully detect BRD bacterial pathogens in house flies. There are benefits and caveats concerning the use of either approach, as demonstrated previously by Gupta et al. [28] and in our study. Our results demonstrated limitations of each technique, since in some instances, bacteria were cultured but not detected by PCR (e.g., in three flies for P. multocida and one fly for M. haemolytica), and PCR detected bacterial DNA but the culturing was unsuccessful (e.g., in five flies for M. haemolytica and one fly for H. somni). These discrepancies could be due to the limitations of both methods to detect specific bacterial pathogens from the complex bacterial communities in the house fly homogenate. Culture-dependent methods target viable bacteria in the fly homogenate, which must out-compete other diverse microorganisms on culture plates in order to be successfully detected and enumerated. Thus, failure of bacteria detection by culture can be attributed to the fastidious nature of many of the target pathogens as well as to antagonistic and competitive actions of other bacteria in the sample. In addition, if the target pathogens are in relatively low abundance compared to other bacteria, then sub-sampling of the homogenate (i.e., plating a sample rather than the whole fly homogenate) can result in under-detection due to abundance below the limits of detection for the assay. Successful culture-independent methods similarly rely on the abundance of the target bacterial cells in the sample and successful DNA extraction followed by amplification of the targeted gene by PCR. While PCR is generally considered to be more sensitive than culture-dependent approaches [28], unsuccessful DNA isolation as well as the low copy number of the target genes can 
result in false-negative results. Additionally, PCR does not discriminate between viable and unviable bacteria, which is important to consider in terms of the potential spread of a disease.

\section{Conclusions}

In conclusion, we demonstrated that house flies collected in the close proximity of cattle with apparent symptoms of BRD harbored M. haemolytica, P. multocida and H. somni. The prevalence of these bacteria in house flies ( $>3 \%$ ) indicates that flies serve as a potential reservoir and/or a vector for these pathogens within feedlots and surrounding areas. Further studies are required to fully understand the vector competence of house flies for BRD pathogens and the extent of risk that house flies, especially females, pose for harbouring and transmitting BRD in the field.

Author Contributions: Conceptualization, S.N. and L.Z.; methodology, S.N.; validation, S.N., D.N. and L.Z.; formal analysis, S.N.; investigation, S.N.; resources, L.Z.; data curation, S.N.; writing - original draft preparation, S.N.; writing-review and editing, S.N., D.N. and L.Z.; visualization, S.N.; supervision, L.Z. and D.N.; funding acquisition, L.Z.

Funding: This work was supported by funding from Central Life Sciences (Dallas, TX, USA).

Acknowledgments: The authors thank Richard Porter for providing information and access to collect house flies in his cattle feedlot and Jessica Thomson for help with house fly collections.

Conflicts of Interest: The authors declare no conflict of interest. The sponsors had no role in the design, execution, interpretation, or writing of the study.

\section{References}

1. Smith, R.A. Impact of disease on feedlot performance: a review. J. Anim. Sci. 1998, 76, 272-274. [CrossRef] [PubMed]

2. Mosier, D. Review of BRD pathogenesis: the old and the new. Anim. Health Res. Rev. 2014, 15, 166-168. [CrossRef] [PubMed]

3. Snowder, G.D.; van Vleck, L.D.; Cundiff, L.V.; Bennett, G.L. Bovine respiratory disease in feedlot cattle: Environmental, genetic, and economic factors. J. Anim. Sci. 2006, 84, 1999-2008. [CrossRef] [PubMed]

4. Taylor, J.D.; Fulton, R.W.; Lehenbauer, T.W.; Step, D.L.; Confer, A.W. The epidemiology of bovine respiratory disease: What is the evidence for predisposing factors? Can. Vet. J. 2010, 51, 1095-1102. [PubMed]

5. Klima, C.L.; Zaheer, R.; Cook, S.R.; Booker, C.W.; Hendrick, S.; Alexander, T.W.; McAllister, T.A. Pathogens of bovine respiratory disease in North American feedlots conferring multidrug resistance via integrative conjugative elements. J. Clin. Microbiol. 2014, 52, 438-448. [CrossRef] [PubMed]

6. Confer, A.W. Update on bacterial pathogenesis in BRD. Anim. Health Res. Rev. 2009, 10, 145-148. [CrossRef] [PubMed]

7. Taylor, J.D.; Holland, B.P.; Step, D.L.; Payton, M.E.; Confer, A.W. Nasal isolation of Mannheimia haemolytica and Pasteurella multocida as predictors of respiratory disease in shipped calves. Res. Vet. Sci. 2015, 99, 41-45. [CrossRef]

8. Wikse, S.E. Feedlot cattle pneumonias. Vet. Clin. N. Am. Food. Anim. Pract. 1998, 1, 289-310. [CrossRef]

9. Moon, R.D. Muscid flies (Muscidae). In Medical and Veterinary Entomology; Mullen, G., Durden, L., Eds.; Academic Press: San Diego, CA, USA, 2009; pp. 275-306.

10. Nayduch, D.; Burrus, R.G. Flourishing in filth: House fly-microbe interactions across life history. Ann. Entomol. Soc. Am. 2017, 110, 6-18. [CrossRef]

11. Ruhland, H.H.; Huddleson, I.F. The role of one species of cockroach and several species of flies in the dissemination of Brucella. Am. J. Vet. Res. 1941, 2, 371-372.

12. Fischer, O.; Matlova, L.; Dvorska, L.; Švástová, P.; Bartl, J.; Melicharek, I.; Weston, R.T.; Pavlik, I. Diptera as vectors of mycobacterial infections in cattle and pigs. Med. Vet. Entomol. 2001, 15, 208-211. [CrossRef] [PubMed]

13. Arsenopoulos, K.; Triantafillou, E.; Filioussis, G.; Papadopoulos, E. Fly repellency using deltamethrin may reduce intramammary infections of dairy cows under intensive management. Comp. Immunol. Microbiol. Infect. Dis. 2018, 61, 16-23. [CrossRef] [PubMed] 
14. Ahmad, A.; Nagaraja, T.G.; Zurek, L. Transmission of Escherichia coli O157: H7 to cattle by house flies. Prev. Vet. Med. 2007, 80, 74-81. [CrossRef] [PubMed]

15. Shanthalingam, S.; Goldy, A.; Bavananthasivam, J.; Subramaniam, R.; Batra, S.A.; Kugadas, A.; Raghavan, B.; Dassanayake, R.P.; Jennings-Gaines, J.E.; Killion, H.J.; et al. PCR assay detects Mannheimia haemolytica in culture-negative pneumonic lung tissues of bighorn sheep (Ovis canadensis) from outbreaks in the western USA, 2009-2010. J. Wildife Dis. 2014, 50, 1-10. [CrossRef] [PubMed]

16. Wei, B.; Cha, S.Y.; Kang, M.; Park, I.J.; Moon, O.K.; Park, C.K.; Jang, H.K. Development and application of a multiplex PCR assay for rapid detection of 4 major bacterial pathogens in ducks. Poult. Sci. 2013, 92, 1164-1170. [CrossRef] [PubMed]

17. Townsend, K.M.; Frost, A.J.; Lee, C.W.; Papadimitriou, J.M.; Dawkins, H.J. Development of PCR assays for species- and type-specific identification of Pasteurella multocida isolates. J. Clin. Microbiol. 1998, 36, 1096-1100. [PubMed]

18. Turner, S.; Pryer, K.M.; Miao, V.P.W.; Palmer, J.D. Investigating deep phylogenetic relationships among cyanobacteria and plastids by small subunit rRNA sequence analysis. J. Eukaryot. Microbiol. 1999, 46, 327-338. [CrossRef]

19. Relman, D.A.; Schmidt, T.M.; MacDermott, R.P.; Falkow, S. Identification of the uncultured Bacillus of Whipple's disease. N. Engl. J. Med. 1992, 327, 293-301. [CrossRef]

20. Altschul, S.F.; Madden, T.L.; Schäffer, A.A.; Zhang, J.; Zhang, Z.; Miller, W.; Lipman, D.J. Gapped BLAST and PSI-BLAST: A new generation of protein database search programs. Nucleic Acids Res. 1997, 25, 3389-3402. [CrossRef]

21. Magwood, S.E.; Barnum, D.A.; Thomson, R.G. Nasal bacterial flora of calves in healthy and pneumonia-prone herds. Can. J. Comp. Med. 1969, 33, 237-243.

22. Panciera, R.J.; Confer, A.W. Pathogenesis and pathology of bovine pneumonia. Vet. Clin. N. Am. Food Anim. Pract. 2010, 26, 191-214. [CrossRef] [PubMed]

23. Ribble, C.S.; Meek, A.H.; Janzen, E.D.; Guichon, P.T.; Jim, G.K. Effect of time of year, weather, and the pattern of auction market sales on fatal fibrinous pneumonia (shipping fever) in calves in a large feedlot in Alberta (1985-1988). Can. J. Vet. Res. 1995, 59, 167-172. [PubMed]

24. Sanderson, M.W.; Dargatz, D.A.; Wagner, B.A. Risk factors for initial respiratory disease in United States' feedlots based on producer collected daily morbidity counts. Can. Vet. J. 2008, 49, 373-378. [PubMed]

25. Gibbs, H.A.; Allan, E.M.; Wiseman, A.; Selman, I.E. Experimental production of bovine pneumonic pasteurellosis. Res. Vet. Sci. 1984, 37, 154-166. [CrossRef]

26. Thomson, J.L.; Yeater, K.M.; Zurek, L.; Nayduch, D. Abundance and accumulation of Escherichia coli and Salmonella typhimurium procured by male and female house flies (Diptera: Muscidae) exposed to cattle manure. Ann. Entomol. Soc. Am. 2018, 110, 1264-1270.

27. Allen, J.W.; Viel, L.; Bateman, K.G.; Rosendal, S.; Shewen, P.E.; Physick-Sheard, P. The microbial flora of therespiratory tract in feedlot calves: associations between nasopharyngeal and bronchoalveolar lavage cultures. Can. J. Vet. Res. 1991, 55, 341-346.

28. Gupta, A.K.; Nayduch, D.; Verma, P.; Shah, B.; Ghate, H.V.; Patole, M.S.; Shouche, Y.S. Phylogenetic characterization of bacteria in the gut of house flies (Musca domestica L.). FEMS Microbiol. Ecol. 2012, 79, 581-593. [CrossRef]

(C) 2019 by the authors. Licensee MDPI, Basel, Switzerland. This article is an open access article distributed under the terms and conditions of the Creative Commons Attribution (CC BY) license (http://creativecommons.org/licenses/by/4.0/). 